Carinthian patriotic association formed whose meetings reminded observers of prewar Nazi rallies. But now these "Nazis" counted as exemplary westerners because they opposed the OF and its efforts to cede territory to communist Yugoslavia.

The anti-Slavic fervor had culminated under Hitler, but obsessions about the Slavization of Austria went back decades, at least to 1867, when they united German and Hungarian liberals in support for the Compromise. In the 1950s, the agenda of pushing back Slavs on Austrian territory (!) brought together reds and blacks who had been divided for decades, and also found much sympathy among browns. Individual clerics gave blessings to old Darwinian notions, according to which the strong (Germans) must prevail. But now the Germans could simply be called Austrians, as an identity deeply insecure since Königgrätz got new underpinnings thanks to the persistence of this tiny "eastern" minority at the height of the Cold War.

The nadir of German-Austrian suppressing of Slavdom came in the late 1950s with a campaign to get parents to "deregister" children from bilingual education. As a result, by the summer of 1959 only 1,673 students remained signed up for bilingual education in a Slovene-speaking population of perhaps 40,000. Among the most fervid Germanizers were Austrians whose grandparents had spoken only Slovenian at home. Still, the "minority" survived, not as full nationality in a "Gellnerian" sense, but as an overlooked option, a preference, an enriching and complementary side of Carinthian and Austrian identity. Knight's eloquently argued book reveals points at which the Austrian state missed chances to treat this unbounded but definite group with basic respect, and should be read by anyone with concern for bi-and multi-cultural coexistence wherever it is endangered.

JOHN CONNELLY

University of California, Berkeley

\title{
AnOther Africa? (Post-)Koloniale Afrikaimaginationen im russischen, polnischen und deutschen Kontext. Ed. Jana Domdey, Gesine Drews-Sylla, Justyna Gołąbek. Akademiekonferenzen, Band 23. Heidelberg: Universitätsver- lag Winter, 2016. 400 pp. Notes. Illustrations. €48.00, paper.
} doi: $10.1017 /$ slr.2018.230

True to its referencing in the title of Chinua Achebe's Another Africa, which mixes Achebe's own verses with Robert Lyons' images in attempting to demolish western stereotypes of Africa, the reviewed bilingual collection of essays, AnOther Africa, has a very ambitious task, namely breaking with the notion that post-colonialism as a discipline belongs only to the west. Situated against the background of postcolonial theories, AnOther Africa, which emerges from a conference hosted by the Heidelberg Academy of Sciences in 2012, delves into the cross-cultural differences from Russian, Polish, and German cultural perspectives with respect to African imagery and colonial references (7). This volume's broadly-conceived collection of papers uses an ambitiously-diverse palette of scientific as well as cultural perspectives and forms of analysis in utilizing historical, ethnological, and discursive phenomena to explain how countries with a relatively limited prior exposure to Africa understood its foreign setting. In so doing, the authors aim to contribute to the recent broadening of the scope and context of postcolonial studies, hitherto reserved to the former western colonial powers, and which previously neglected central and eastern Europe from postcolonial debates and discourses. Therefore, the volume concentrates on three philologies, Russian, Polish and German, which have only relatively recently opened up to the originally Anglophone-dominated postcolonial discourse. 
The fifteen essays in this volume attempt to amalgamate the study of African representations with the central and east European context, which is currently replete with intensified discussions of east-south interactions, despite the initial skepticism and circumspection. The cases of Poland, Russia, and Germany, however, are not as homogeneous as they may seem at a first glance, regardless of their non-western spatial and cultural positioning, as part of the "Other Europe" during the Cold War. One of this volume's major contributions is that it demonstrates the differences in the way the three countries with non-existing direct colonializing experience during the nineteenth century's scramble for Africa interpreted African imageries, histories, and experiences. For example, the German academia, in general, and German philology, in particular, have long been strongly opposed to the recognition of the relevance of postcolonial studies for Germany's own national context. AnOther Africa, however, follows up on recent developments in the German literary domain, by interpreting recent works by Thomas von Steinaecker, Urs Widmer, Alex Capus, and Arnold Stadler (see Jana Domdey, Michaela Holdenried, and Nadjib Sadikou's essays) through postcolonial analytical optics. Polish literary discourse on Africa, on the other hand, is somewhat different. As Justyna Gołąbek's essay claims, the Polish ruminations over Africa are conceptually predicated on the figure of the colonized colonizer (skolonizowany kolonizator), which describes Poland's entanglement as having been dominated by German and Russian hegemonic powers at home, on the one hand, and its experience as a hegemonic power in its eastern peripheral regions, on the other. There is also a double perspective for the Russian Africa discourse. Tsarist Russia and the Soviet Union were both imperial powers in Siberia, Central Asia, and the Caucasus, while Moscow's outward-looking political modus vivendi became notable in Africa during the Cold War despite its ideologically anti-colonialist arguments.

The volume is divided into four parts. The four essays in the first part are interpreting African discourse in Soviet, Polish, and East German travels, tracing the colonial-romanticism in Soviet adventure literature (Matthias Schwartz), Africadiscourse and history politics in recent German novels (Dirk Göttsche), modernity, race, and images of Africa in Soviet cinema (Irina Novikova), and postcolonial reflection in Polish popular travel books (Justyna Tabaszewska). The second portion of the book looks into various shifts and projections of multi-coding and decoding of Africa's realities by looking into the literary discourses developed in Polish writings on Africa in the nineteenth century by Rehman and Sienkiewicz (Paweł Zajas, Dirk Uffelmann) and the ways of transforming postcolonial discourse into aesthetic forms in German literature (Sadikou, Domdey). The four papers in the third part delve into socialist and post-socialist reflections of Africa in the Soviet Union from the point of view of those looking out into Africa, such as Soviet scholars (Apollon Davidson and Irina Filatova) and students coming from Africa (Svetlana Boltovskaja). This segment also broadens the volume's scope by focusing on West German perceptions of South Africa (Ingrid Laurien) while acknowledging modern literary discourses dealing with GDR's past (Carlota von Maltzan). Finally, the last three essays cut across historic layers by alternating visions, originating from Rogoziński's nineteenth century Polish expedition to Cameroon (Justyna Gołąbek), through contemporary German narrative strategies of inversion of colonial past (Michaela Holdenried), to deconstructivist aesthetics of Russian-Soviet postmodernism in Efrofeev's Pyat' rek zhizni (Gesine Drews-Sylla).

In sum, looking for faults in conference proceedings resulting in a collaborative volume for the sake of completeness is a dubious exercise in academic indulgence. Granted, this volume will unlikely score with the completeness of its case studies, however eclectic and multidisciplinary they are. However, this book's main virtue is that it boldly places the postcolonial discourse into national literary domains 
originating from nations unrelated to the colonial scramble for Africa. In its modern multipolar approach, the collection not only pays tribute to the intellectual heritage of Edward Said, Frantz Fanon, Homi Bhaba, and Gayatri Chakravorty Spivak, whose influence is felt throughout the volume, but also boldly attempts to decode Africa's colonial past through the lens of Germany, Poland, and Russia, previously unlikely actors in postcolonial discourse. While this premise might seem synthetic to some die-hard purists, it is not without scholastic merits. Accordingly, in moving postcolonial discourse not only into new pastures but also into the twenty-first century, by employing a bricolage of modern interpretative techniques, this collective exercise succeeds in demonstrating that in the postcolonial world there is always room left for yet Another, even if less expected, Other.

RADOSLAV YORDANOV

Davis Center for Russian and Eurasian Studies Harvard University

Geschichte als Politikum: Lettland und die Aufarbeitung nach der Diktatur. By Katja Wezel. The Baltic Sea Region: Northern Dimensions-European Perspectives no.15. Berlin: Berliner Wissenschafts Verlag, 2016. 324 pp. Appendix. Bibliography. Index. Illustrations. Photographs. Tables. €49.00, paper.

doi: 10.1017/slr.2018.231

For at least the last two decades, the politics of memory in Latvia has been formulated and performed by various actors who mainly define their political position based on the results of World War II in Latvia. Long before the term "politics of history" had been invented in relation to the attempts of Vladimir Putin's government to revise the image of Soviet Russia in the history of twentieth century eastern Europe, in the Baltics, and Latvia especially, politics of collective remembrance had been used as an effective tool to mobilize various ethnic groups for political purposes. The Second World War in the Baltics is not yet over, on the contrary, it is still continuing in political discourses, although the countries have changed dramatically-parliamentary elections, NGOs, annual festivals and commemoration events, and books and conferences have become the site of the battle for political affiliation and voters' sympathies. Although various Latvian specialists in memory politics have done much to explain the peculiar results of WWII to the population of Latvia, there is still a major challenge remaining for Latvian politics of inclusion: how does one find a place for the experience of the war and its results that opposes the predominant narrative of the war and occupation still circulating among the various minorities in Latvia? How can those who have fought on the side of the Red Army and who are ethnic Latvians also be included in this narrative? How can creating new, mnemonic gaps and clashes over historic events that are often the predominant content of political propaganda that receives tremendous media support from abroad be avoided? How can we avoid fake history in the culture of "politainment," where fake news and interpretations become an attractive basis for collective identities for minorities?

All these difficult questions have been addressed in a new academic study by Katja Wezel, who is well known for her interest in Latvian memory politics. Her book is the result of long-term research into the collective traumas of various ethnic groups in Latvian society. After introducing the reader to the peculiarities and conflicts of Latvian history in the twentieth century, Wezel proceeds to the important issue of the national movement in the late 1980s, which in Latvian is still called awakening (atmoda), but which in Wezel's version is described as a movement for Latvian autonomy. This is certainly the point where officials in contemporary Latvia would 